\title{
Unintended consequences of the potential phase-out of
}

\section{gamma irradiation [version 1; peer review: 2 approved]}

Jacquelyn W Chou'1, Michelle Skornicki (D1) Joshua T Cohen²

${ }^{1}$ Precision Health Economics, Los Angeles, CA, USA

${ }^{2}$ Tufts Medical Center, Boston, MA, USA

V1 First published: 21 Mar 2018, 7:348

https://doi.org/10.12688/f1000research.14090.1

Latest published: 21 Mar 2018, 7:348

https://doi.org/10.12688/f1000research.14090.1

\begin{abstract}
The radioisotope cobalt-60 (Co-60) is important for commercial, medical, and agricultural applications. Its widespread use has meant that Co-60 can be found in less secured facilities, leading to the fear that unauthorized persons could obtain and use it to produce a "dirty bomb". This potential security concern has led to government calls for phasing-out Co-60 and other radiation sources, despite ongoing safety and security regulations for handling, transport and use of radioactive sealed sources.
\end{abstract}

This paper explores potential implications of phasing out radioisotopic technologies, including unintended safety and cost consequences for healthcare and food in the US and globally.

The use of Co-60 for healthcare and agricultural applications is welldocumented. Co-60 is used to sterilize single-use medical devices, tissue allografts, and a range of consumer products. Co-60 is used in Gamma Knife treatment of brain tumors in over 70,000 patients annually. Co-60 is also used to preserve food and kill insects and pathogens that cause food-borne illness.

Co-60 is effective, reliable, and predictable. Limitations of alternative sterilization technologies include complex equipment, toxicities, incompatibilities with plastic, and physical hazards. Alternative ionizing radiation sources for wide-reaching applications, including ebeam and x-ray radiation, have advantages and drawbacks related to commercial scale capacity, penetrability, complexity and reliability.

Identifying acceptable alternatives would require time, costs and lengthy regulatory review. FDA testing requirements and other hurdles would delay replacement of existing technologies and slow medical innovation, even delaying access to life-saving therapies. A phase-out would raise manufacturing costs, and reduce supply-chain efficiencies, potentially increasing consumer prices, and reducing supply.

\section{Open Peer Review \\ Approval Status \\ 12 \\ version 1 \\ 21 Mar 2018

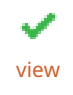 \\ $\checkmark$ \\ 1. Steven J. Goetsch, San Diego Gamma Knife \\ Center, San Diego, USA \\ Radiological Technologies University VT, \\ South Bend, USA \\ 2. L. John Schreiner, Queen's University, \\ Kingston, Canada \\ Cancer Centre of Southeastern Ontario at the Kingston Health Sciences Centre, Kingston, \\ Canada}

Any reports and responses or comments on the article can be found at the end of the article. 
These consequences are poorly understood and merit additional research. Given Co-60's importance across medical and non-medical fields, restrictions on Co-60 warrant careful consideration and evaluation before adoption.

Keywords

Sterilization; Co-60; gamma irradiation

Corresponding author: Jacquelyn W Chou (jacki.chou@pheconomics.com)

Author roles: Chou JW: Conceptualization, Funding Acquisition, Investigation, Methodology, Project Administration, Supervision, Validation, Writing - Original Draft Preparation, Writing - Review \& Editing; Skornicki M: Investigation, Methodology, Writing - Original Draft Preparation, Writing - Review \& Editing; Cohen JT: Conceptualization, Investigation, Methodology, Validation, Writing - Review \& Editing

Competing interests: Skornicki and Chou are employed by Precision Health Economics. Cohen serves as a consultant to Precision Health Economics. The authors have no competing interests to disclose.

Grant information: Sterigenics provided financial support for this research to Precision Health Economics.

Copyright: ๑ 2018 Chou JW et al. This is an open access article distributed under the terms of the Creative Commons Attribution License, which permits unrestricted use, distribution, and reproduction in any medium, provided the original work is properly cited.

How to cite this article: Chou JW, Skornicki M and Cohen JT. Unintended consequences of the potential phase-out of gamma irradiation [version 1; peer review: 2 approved] F1000Research 2018, 7:348 https://doi.org/10.12688/f1000research.14090.1

First published: 21 Mar 2018, 7:348 https://doi.org/10.12688/f1000research.14090.1 


\section{Introduction}

Naturally occurring cobalt is a stable element. One of its synthetic isotopes, Cobalt-60 (Co-60), has an extra neutron in its nucleus that makes it unstable. As it breaks down, Co-60 emits high energy, "ionizing" radiation that can break molecular bonds. Co-60 plays an important role in a wide variety of commercial, medical, agricultural and research applications because it is a "radioisotope" and hence generates steady, predictable ionizing radiation.

One of the most useful applications of radioisotopes in general and Co-60 in particular is sterilization. The list of single-use medical devices sterilized using Co-60 is lengthy, including surgical instruments, gloves, gowns, dressings, masks, catheters, laparoscopic equipment, implants, probes, and other objects that enter sterile tissue or the vascular system. Another major healthcare use of Co-60 is the sterilization of tissue allografts, including bone, skin, amniotic membrane and soft tissues used to treat severe burns, non-healing ulcers, and to facilitate organ transplants ${ }^{1,2}$. (https://www.aatb.org/?q=about-us) Co-60 is also used to sterilize consumer products such as bottle teats for premature babies, medical bandages and a variety of personal health and hygiene products, and raw materials for cosmetics ${ }^{3,4}$. (https://www.nei.org/Knowledge-Center/ Other-Nuclear-Energy-Applications/Consumer-Products)

A second critical application of Co-60 is cancer treatment. Gamma Knife technology, developed in 1968, uses gamma radiation to target small brain tumors. By precisely targeting high doses of ionizing radiation generated by Co-60, Gamma Knife therapy can treat small brain tumors while mitigating damage to surrounding normal, healthy tissue. Gamma Knife therapy is used in over 70,000 patients annually,5. (http:// gammaknife.com/what-is-gamma-knife/)

Co-60 has also been used since the 1920 s to preserve food. (https://www.fda.gov/food/ingredientspackaginglabeling/ irradiatedfoodpackaging/ucm081050.htm.) By killing microorganisms, insects, and pathogens that can cause food-borne illness, such as salmonella and escherichia coli (E. coli), ionizing radiation extends food shelf life and improves food safety $^{7,8}$. (https://www.fda.gov/food/ingredientspackaginglabeling/ irradiatedfoodpackaging/ucm081050.htm)

Because they produce radiation, radioisotopes have raised security concerns. The fear is that loss of radioisotopes - due to accident, oversight, or sabotage - could result in their acquisition by unauthorized persons or terrorists who could then produce a radiological dispersal device ("dirty bomb") $)^{9}$. Motivated by these concerns, some members of Congress proposed legislation in the 2015 Appropriations Bill that would have phased out the use of radioisotopes in the United States, including Co-60. (http://www.nrc.gov/reading-rm/doc-collections/cfr/part020/) Though that legislation did not pass, the suggestion that use of Co-60 and other radioisotopes should be phasedout has persisted. In 2015, the Committee on Homeland and National Security created the Interagency Working Group on Alternatives to High-Activity Radioactive Sources (GARS) to develop best practices to transition to non-radioisotopic technologies.

This paper explores the merits and potential downside of shifting away from radioisotopic technologies. We describe unintended safety and cost consequences of a Co-60 phase-out for healthcare and food applications.

\section{Rationale for phase-out of Co-60}

The widespread commercial use of Co-60 means it is often housed in less well-guarded facilities, such as hospitals, that are unlike heavily guarded nuclear facilities?. Experience in other countries has demonstrated the potential for mishaps. For example, in 2013, thieves in Mexico stole a truck transporting Co-60. The thieves ultimately abandoned the Co-60, as the material itself did not appear to be the target, and the authorities recovered $\mathrm{it}^{10}$. Also in 2013, online fashion retailer Asos recalled a batch of metal-studded belts contaminated with Co-60 likely introduced in scrap metal from India or another Asian country ${ }^{11}$. In both of these cases, it was incidental exposure to Co-60 that posed the greatest public health risk, rather than the potential for a terrorist act. To date, these types of Co-60 mishaps have not been reported in the United States, perhaps because of this country's stricter regulations. There have been no deaths from exposure to radiation or any history of contaminated groundwater at irradiators in the US. The US Nuclear Regulatory Commission (NRC) has reviewed cases of radiation incidents and has developed strict requirements designed to reduce future risk of incidents (10 CFR (Code of Federal Regulations) Part 36, implemented in 1993.) (https:// www.nrc.gov/reading-rm/doc-collections/fact-sheets/commercialirradiators.html)

Ongoing regulatory changes and additional safety and security requirements have been implemented over the years to further increase and assure maintenance of safe and secure handling, transport and use of high activity radioactive sealed sources. The US NRC promulgated 10 CFR Part 37 in March 2013 with adoption required by US NRC licensees by March 2014 and Agreement State licensees by March 2016. (https://www.nrc.gov/reading-rm/doc-collections/cfr/part037/) Part 37, "Physical Protection of Category 1 and Category 2 Quantities of Radioactive Material", provides specific detail of control in the following areas:

i) Background investigation and access control program of people and facilities (criminal history checks and related other elements of personnel involved in handling, transport, and use of this material; access authorization to areas where such material is housed; personnel access authorization and control where material is used; and protection of information)

ii) Physical protection requirements during use (comprehensive security program for facilities and people; security zones; monitoring/detection/assessment; maintenance, testing; security program review; reporting of events) 
iii) Physical protection in transit, including preplanning and coordination of transit; physical protection during transit; and personnel/vehicle controls

iv) Record keeping, and

v) Enforcement

\section{Desirable properties of Co-60}

Co-60 has three main advantages. First, the gamma radiation it produces is versatile. Gamma radiation can deeply penetrate a wide range of low- and high-density materials ${ }^{1,12,13}$. Deep penetration is important for sterilizing medical supplies and to reach pathogens deep within the food matrix ${ }^{14}$. Because gamma radiation does not require high temperature, it can be used on temperature-sensitive items, products can be irradiated in bulk, and sterilization can take place after final packaging ${ }^{15,16}$.

Second, Co-60 is reliable. It has a simple and predictable decay pattern and a relatively long half-life (5.27 years). Treatment with Co-60 is precise and reproducible: ${ }^{15,17-19}$ (http://www.worldnuclear.org/information-library/non-power-nuclear-applications/ radioisotopes-research/radioisotopes-in-medicine.aspx, http:// www.world-nuclear.org/information-library/non-power-nuclearapplications/overview/the-many-uses-of-nuclear-technology.aspx) therefore, instrument calibration standards rely on Co-60 as a "gold standard" yardstick ${ }^{20}$. Co-60 gamma irradiators are simple to use and control ${ }^{1,3,12}$, and because the Co-60 itself generates the radiation, it is energy-efficient ${ }^{15}$. These properties minimize operational maintenance requirements ${ }^{15}$.

Finally, Co-60 has favorable physical characteristics that make it ill-suited to manipulation that could pose security risks. It cannot start a fission chain reaction, it is non-flammable, and it cannot poison a water supply because it is insoluble. Moreover, because Co-60 is not readily dispersible, it does not emit neutrons or leave residues, or cause other surrounding materials to become radioactive ${ }^{15,16}$.

\section{Limitations of Co-60 alternatives}

Alternative sterilization technologies include chemical treatment, non-ionizing radiation, and other ionizing radiation sources (Table 1). Chemical treatments pose a series of challenges. ${ }^{1,21}$. Ethylene oxide (EO) requires complex equipment, is toxic, and flammable, and poses an explosive hazard. EO can be inconsistent because its use depends on multiple variablesincluding temperature, time, pressure, vacuum, and concentration-to address differences in the target material's physical characteristics (e.g., density and porosity), packaging, and humidity ${ }^{3,12}$. Peracetic acid-ethanol, although rapid $^{22}$ and compatible with a wide variety of materials, significantly reduces biomechanical strength, decreases remodeling activity in ligament grafts $^{1}$ and does not reduce infection risk $^{22}$. Heat treatment damages many materials. For example, steam autoclaving damages plastics which comprise many single-use items. Although evidence is limited and it can only treat heat-resistant materials ${ }^{22}$, microwave treatment has been shown to effectively sterilize some bone allografts ${ }^{1}$.

Alternative ionizing radiation sources have both advantages and drawbacks. Like gamma radiation, e-beam can sterilize health care products on a commercial scale ${ }^{1}$ and is currently used in many large facilities. E-beam delivers radiation rapidly and can be scaled ${ }^{3}$. However, because the radiation is machinegenerated, rather than a material by-product (as is the case with Co-60-generated gamma radiation), the equipment is complex and costly to install and operate. Nor is e-beam radiation as predictable or uniform as Co-60 gamma radiation ${ }^{1}$. Finally, e-beam radiation does not penetrate materials as well as gamma radiation. $\mathrm{X}$-ray radiation achieves penetration comparable to that achieved by gamma rays ${ }^{3}$. However, similar to equipment used to generate e-beam, x-ray generating equipment is complex, expensive and less reliable than Co-60, with very few such sterilization units operating globally $y^{3,13,17,23}$. (http://www.world-nuclear.org/ information-library/non-power-nuclear-applications/overview/ the-many-uses-of-nuclear-technology.aspx, http://www.iaea.org/ inis/collection/NCLCollectionStore/_Public/29/057/29057259.pdf)

\section{Impacts - Medical - United States}

Because ionizing radiation has desirable properties and radioisotopes reliably generate this type of radiation, limiting the use of radioisotopes could have implications for medical care, including single-use medical supplies, allografts, and therapeutic technologies. These impacts extend beyond the US population since the US supplies a significant amount of sterile medical devices globally.

\section{Sterilization of single-use medical supplies}

Current estimates indicate that the sterilization industry is divided between EO (50\%), gamma (40.5\%), e-beam (4.5\%) and other (including x-ray) (5\%), and there are 200 healthcare facilities worldwide with commercial gamma sterilization capability $^{23}$. Co-60 is the most widely used form of radiation for sterilizing single-use medical products ${ }^{16}$, as heat sterilization is often damaging, and alternative methods might not achieve sufficient penetration ${ }^{17,23}$. (http://www.world-nuclear. org/information-library/non-power-nuclear-applications/overview/the-many-uses-of-nuclear-technology.aspx) Single-use medical products were used in over 52 million surgical procedures in the US in 2011 , with $45 \%$ of single-use products sterilized using Co- $60^{23,24}$.

Curtailing radioisotope sterilization would make availability of some single-use products uncertain, hence potentially jeopardizing millions of surgical procedures yearly. At the very least, products for which the effectiveness of alternative sterilization technologies has not been established would have to undergo significant and both time and cost intensive testing ${ }^{25,26}$. In the case of products for which adequate sterilization proved infeasible, single-use medical products could become unavailable going forward. Predicting the impact of this disruption 
Table 1. Comparison of Cobalt-60 Sterilization Alternatives.

\begin{tabular}{|c|c|c|}
\hline $\begin{array}{l}\text { Type of } \\
\text { Sterilization }\end{array}$ & Advantages & Challenges \\
\hline Gamma radiation & $\begin{array}{l}\text { - Can be used to sterilize health care products on a } \\
\text { commercial scale }{ }^{1} \\
\text { - Simplicity and reliability of irradiation equipment, } \\
\text { the radiation source and ability to match source } \\
\text { strength to production throughput (http://www. } \\
\text { iaea.org/inis/collection/NCLCollectionStore/__ } \\
\text { Public/07/220/7220308.pdf\#page=280) } \\
\text { - Scalability for different throughput } \\
\text { - } \quad \text { Reactor-produced from metal }{ }^{59} \text { Co, and therefore } \\
\text { has a finite production cost (http://www. } \\
\text { iaea.org/inis/collection/NCLCollectionStore/_- } \\
\text { Public/07/220/7220308.pdf\#page=280) }\end{array}$ & $\begin{array}{l}\text { - Not suitable for small scale } 22 \\
\text { - Requires requalification of irradiator operation after } \\
\text { - Source replenishments }{ }^{23} \\
\text { equipment associated with gamma radiation } \\
\text { include induced oxidation in polyethylene and } \\
\text { delamination and cracking in polyethylene knee } \\
\text { bearings }{ }^{22}\end{array}$ \\
\hline $\begin{array}{l}\text { Electron beams } \\
\text { (E-beam) }\end{array}$ & $\begin{array}{l}\text { - Can be used to sterilize health care products on a } \\
\text { - } \quad \text { Neammercial scale }{ }^{1} \\
\text { - } \quad \text { Scalability for different throughput } \\
\text { - } \quad \text { Capability to integrate in an on-line process }{ }^{3} \\
\text { - } \quad \text { Short processing time } \text { pro }^{23}\end{array}$ & $\begin{array}{l}\text { - Higher costs for accelerator investment and } \\
\text { operations than gamma - not suitable for small } \\
\text { scale } \\
\text { - Complex irradiation equipment design and higher } \\
\text { maintenance costs / downtime than Co- } 60 \\
\left.\text { - Low penetrability (bulk densities up to } 0.25 \mathrm{~g} / \mathrm{cm}^{22}\right)^{23} \\
\text { Dose distribution through the irradiated product is } \\
\text { less uniform than with gamma radiation }\end{array}$ \\
\hline X-rays & $\begin{array}{l}\text { - } \quad \text { Comparable penetration to gamma rays } \mathrm{s}^{3,23} \\
\text { - Recent developments in high current e-beam } \\
\text { accelerators for X-rays }{ }^{3} \text { make it more practical }\end{array}$ & $\begin{array}{l}\text { - Limited use, uncertain operating and usage cost } \\
\text { estimates }{ }^{3} \\
\text { - Higher costs for accelerator investment and } \\
\text { operations than e-beam and gamma - not suitable } \\
\text { for small scale22 } \\
\text { - Complex irradiation equipment design and } \\
\text { potentially higher initial capital costs than gamma } \\
\text { and higher maintenance costs / downtime than } \\
\text { E-beam and Co-6023 } \\
\text { Accelerator source used for x-ray is less reliable } \\
\text { than Co-60 for cargo container contraband and } \\
\text { security screening applications (http://www. } \\
\text { iaea.org/inis/collection/NCLCollectionStore/_ } \\
\text { Public/29/057/29057259.pdf) }\end{array}$ \\
\hline Ethylene oxide & $\begin{array}{l}\text { Widest range of material compatibility except for } \\
\text { moisture and temperature-sensitive materials }(>30 \\
\text { degrees } \mathrm{C} \text { and/or }<30 \% \mathrm{RH})^{23}\end{array}$ & $\begin{array}{l}\text { - Hazardous (toxicity issues, explosive) })^{23} \\
\text { - } \quad \text { Mang processing time }{ }^{23} \\
\text { pressure, vacuum, gas concentration, packaging } \\
\text { and humidity) } \\
\text { - Time-consuming for routine use between patients } \\
\text { - } \quad \text { Package and all parts of product to be sterilized } \\
\text { must be gas permeable, irrespective of density }{ }^{23}\end{array}$ \\
\hline Steam & $\begin{array}{l}\text { - Preferred for aqueous preparations only } \\
\text { - } \quad \text { Economical and short processing time; } \\
\text { - } \quad \text { Nontoxic and safe for the environment }{ }^{12}\end{array}$ & $\begin{array}{l}\text { - Strict temperature and moisture controls; } \\
\text { - } \quad \text { Many variables to control (temperature, time, } \\
\text { - } \quad \text { Cannosure, vacuum, packaging and humidity) } \\
\text { - }\end{array}$ \\
\hline $\begin{array}{l}\text { Peracetic acid- } \\
\text { ethanol }\end{array}$ & $\begin{array}{l}\text { - Established sterilization of bone, dermis and } \\
\text { amniotic membrane transplants with no evidence of } \\
\text { impaired transplant properties } \\
\text { - } \quad \text { Rapid sterilization time } \\
\text { - } \quad \text { Less damaging process to delicate materials than } \\
\text { steam; } \\
\text { - Compatible with a wide variety of materials-plastics, } \\
\text { rubber, and heat-sensitive items; } \\
\text { - Single-use process, there is no possibility of } \\
\text { contamination }{ }^{12} \\
\text { - Faster cycle times than } \mathrm{EO}^{22}\end{array}$ & $\begin{array}{l}\text { - Has caused significantly reduced biomechanical } \\
\text { strength and decreased remodeling activity in } \\
\text { anterior cruciate ligament reconstruction tendon } \\
\text { grafts }{ }^{1} \\
\text { - Lack of evidence on reduction in infection risk and } \\
\text { link to improved patient care }{ }^{22}\end{array}$ \\
\hline Thermodisinfection & $\begin{array}{l}\text { - Found to preserve tensile strength necessary for } \\
\text { clinical purposes }\end{array}$ & - Small-scale \\
\hline Microwave & $\begin{array}{l}\text { Effective for sterilization of bone allografts processed } \\
\text { from femoral heads contaminated with Gram-positive } \\
\text { and Gram-negative bacteria }\end{array}$ & $\begin{array}{l}\text { - } \quad \text { Lack of evidence on efficacy }{ }^{1} \\
\text { - Can only be used with items that do not melt }\end{array}$ \\
\hline
\end{tabular}


on health is difficult. We do not know how many technologies would be affected, for how long, or the adequacy of substitute or redesigned products. However, with the possibility that millions of surgeries could be affected, it is clear that curtailing use of radioisotope materials for single-use medical supply sterilization could be highly disruptive.

\section{Tissue allograft sterilization}

More than 2 million allografts each year support more than 1 million annual tissue transplants ${ }^{2}$. Used in reconstructive surgery for musculoskeletal injuries, allografts avoid the major complications associated with use of autogenic materials ${ }^{1}$. In addition, allograft skin and amniotic membrane have unique properties that make them irreplaceable and indispensable in the treatment of serious burn injuries ${ }^{1}$. The risk of transmitting infectious disease from donor to recipient necessitates sterilization.

Sterilization alternatives for tissue allografts (ethylene oxide, peracetic acid-ethanol, thermo-disinfection), microwave, electron beam) lack the same demonstrated effectiveness as gamma radiation $^{1,21}$. Studies have identified insufficient penetration as a key limitation of alternative sterilization technologies ${ }^{1}$. Although some evidence indicates that microwave sterilization is effective for bone allografts ${ }^{28}$, evidence supporting microwave sterilization in general, and its use for other tissues is limited compared to the evidence for gamma radiation.

Even if more extensive evidence were available, a phase-out of radioisotope sterilization could trigger FDA regulatory testing requirements $^{21}$ and delay replacement of existing sterilization technologies, potentially affecting the supply of tissue allografts.

\section{Gamma knife surgery}

Gamma Knife is a stereotactic radiosurgery technique that relies on Co-606 . Approximately 70,000 Gamma Knife surgeries take place worldwide each year, with nearly 1 million surgeries having been conducted from 1991-2013. (https:// gammaknife.com/downloads/Facts\%20in\%20short_1028438.01. pdf) While alternatives exist, the Gamma Knife technique, described in Table 2, is the most established, well-researched and validated form of radiosurgery. (http://nyulangone.org/locations/ center-for-advanced-radiosurgery/gamma-knife-radiosurgery)

Gamma Knife is specifically indicated for brain surgeries. Radiosurgery using Co-60 is non-invasive and accurate to $0.15 \mathrm{~mm}$. Because it can target small areas, Gamma Knife can be used more extensively than competing technologies that deliver larger tissue doses of radiation because they cannot be as finely focused $^{29,30}$. The more precise targeting achieved by Gamma Knife also causes less damage to healthy tissue, speeding recovery and minimizing side effects ${ }^{31}$. In a prospective cohort study in which physicians assigned and treated patients with either gamma knife radiosurgery or whole brain radiotherapy (follow-up of 1200 days, or 3.3 years), the mortality rate was lower for Gamma Knife patients $(74.4 \%$ vs. $97.1 \%)$, and the median survival time greater (9.5 months for Gamma Knife versus 8.3 months for whole brain radiotherapy patients) ${ }^{32}$. With approximately 70,000 gamma knife surgeries each year ${ }^{6}$ and 1.2 added months (9.5-8.3) gained per surgery, eliminating Gamma Knife could potentially cost 7,000 life-years annually. Curtailing Co-60, which the Gamma Knife depends on, would eliminate the only demonstrated treatment for certain tumor types.

\section{Slowed innovation}

A ban on radioisotope sterilization technologies could also slow medical innovation. Modifications to sterilization modalities could involve costly redesign and require additional validation for the sterilization process, the sterilization product itself, and its packaging ${ }^{23}$. First, altering the sterilization method constitutes a major change to new drug applications (NDA) and abbreviated new drug applications (ANDA), requiring FDA approval prior to distribution of drug products ${ }^{26}$. The added effort could divert resources away from development of new technologies. Alternative sterilization methods may require new 510(k) or premarket applications (PMA). For 510(k) applications, the FDA determines whether the device is at least as safe and effective as a legally marketed device ("substantial equivalence" $)^{5,8}$. Although the process is supposed to take

Table 2. Stereotactic Radiosurgery Alternatives (http://www.irsa.org/radiosurgery.html).

\begin{tabular}{|c|c|c|c|}
\hline & Cobalt-60 & Particle beam & Linear accelerator base \\
\hline Treatment Area & $\begin{array}{l}\text { Ideal for small brain tumors (less than } \\
3.5 \mathrm{~cm} \text { ) and functional disorders of the } \\
\text { brain }\end{array}$ & $\begin{array}{l}\text { Brain tumors and body } \\
\text { cancers }\end{array}$ & $\begin{array}{l}\text { Large brain tumors (over } 3.5 \text { ) cm, } \\
\text { body cancers, head, and neck }\end{array}$ \\
\hline Length of Treatment & One-day treatment & Multiple day treatments & Several sessions \\
\hline $\begin{array}{l}\text { Amount of Supportive } \\
\text { Evidence }\end{array}$ & $\begin{array}{l}\text { Available for over } 40 \text { years, substantial } \\
\text { amount of published research supporting } \\
\text { efficacy and usage }\end{array}$ & $\begin{array}{l}\text { Little supportive } \\
\text { research due to cost of } \\
\text { a facility }\end{array}$ & $\begin{array}{l}\text { Lack of peer-reviewed research about } \\
\text { diagnosis and treatment }\end{array}$ \\
\hline Additional Benefits & $\begin{array}{l}\text { Better targeting } \\
\text { Less damage to healthy tissue } \\
\text { Fewer complications }\end{array}$ & & $\begin{array}{l}\text { More flexibility over larger areas and } \\
\text { spreading treatments over several days }\end{array}$ \\
\hline $\begin{array}{l}\text { Common Brand } \\
\text { Names }\end{array}$ & Gamma Knife & -- & Novalis Tx, CyberKnife, TomoTherapy \\
\hline
\end{tabular}


no more than 90 days, one sterilization company noted that the full FDA clearance process lasts 9 months. (http://www. revoxsterilization.com/sites/default/files/Revox_OsteoArticle.pdf) The FDA believes that novel sterilization technologies "carry a substantial risk of inadequate sterility assurance if not conducted properly". (https://www.fda.gov/downloads/MedicalDevices/.../ucm109897.pdf) Therefore, recent guidance indicates that in the context of a novel sterilization process, FDA intends to inspect manufacturing facilities before clearing a $510(\mathrm{k})$. (https://www.fda.gov/downloads/MedicalDevices/.../ucm109897. pdf) PMA applications or supplements require up to 180 days of review time, depending on the product's regulatory classification, design, and other required changes ${ }^{5}$.

Second, because these reviews will divert FDA's resources, FDA's approval of other new technologies will likely slow. The FDA already has a backlog of products awaiting approval. Further slowing the overburdened approval system could delay patient access to life-saving therapies ${ }^{33}$. (https://www.cato.org/ publications/commentary/fda-can-be-dangerous-health)

Third, a Co-60 phase-out will raise manufacturing costs. It costs on average $\$ 31$ million to bring a low-to-moderate $510(\mathrm{k})$ product from concept to market, with approximately threequarters of the cost related to FDA-dependent or related activities. Costs for PMAs are \$94 million, with $\$ 75$ million related to the FDA process ${ }^{34}$. By raising costs, a Co-60 phase-out could disincentivize future innovation.

Finally, Co-60 sterilization facilities are often located near medical device manufacturers or distribution hubs. Phasing out of these facilities would reduce the attendant supply chain efficiencies, potentially increasing consumer prices, delaying product availability, and reducing supply.

\section{Impacts - Non-Medical - United States}

Because of the reliability and predictability of Co- 60 for sterilization, its use extends beyond medical products. A phase-out has implications for both the food supply and the multitude of consumer goods that use Co-60 for sterilization.

\section{Food products}

The US food supply relies heavily on gamma radiation. Co-60 is used for food preservation, shelf-life extension, and reduction of food-borne illness for domestic and international food products, including microbial disinfection of spices. (http://www.fda. gov/NewsEvents/Newsroom/PressAnnouncements/ucm279485. htm) Most spices sold in the US are grown overseas in developing countries, where pollution and water issues can contaminate food shipped to this country. (http://www.washingtonpost.com/ wp-dyn/content/article/2010/03/13/AR2010031301111.html) Irradiation is also used as a quarantine treatment for fresh horticultural commodities, and as a substitute for fumigants in Asian countries and the US ${ }^{7}$. (https://uw-food-irradiation.engr.wisc.edu/ Process.html)

Phasing-out Co-60 will likely affect US and global food supply chains as alternatives are established. Alternatives to Co-60 have characteristics that limit their ability to treat all food products requiring irradiation. Because gamma irradiation can completely penetrate a product, it can deactivate both surface pathogens and those found within the food matrix (see Table 3$)^{14}$. With almost a quarter of the world's food irradiation units located in the US ${ }^{35}$, switching to alternatives to Co-60 irradiation may cause some disruption to the global food supply system. There is potential for impacts to food prices, supply, and access, depending on how quickly the global food irradiation system would be able to respond to a US phase-out.

\section{Decommissioning costs}

Like food products, consumer goods prices will likely increase in response to a Co-60 phase-out, as decommissioning current Co-60 facilities will be costly. In February 1999, a decommissioning project commenced for a gamma irradiation facility at the Brookhaven National Laboratory (BNL), located on Long Island, New York ${ }^{36}$. The decommissioning process

Table 3. Sterilization Alternatives for Food Products.

\begin{tabular}{|c|c|c|}
\hline $\begin{array}{l}\text { Type of } \\
\text { Sterilization }\end{array}$ & Advantages & Challenges \\
\hline Gamma rays & $\begin{array}{l}\text { Penetrate fully to reach surface pathogens and those } \\
\text { found within the food matrix }{ }^{14} \text {; insignificant rise in } \\
\text { temperature; high penetrating power; simple process } \\
\text { to control }{ }^{3}\end{array}$ & \\
\hline $\begin{array}{l}\text { Electron beam } \\
\text { (E-beam) }\end{array}$ & Sterilization effectiveness comparable to gamma rays ${ }^{3}$ & $\begin{array}{l}\text { Limited depth; Limited by the penetration } \\
\text { of electrons (which is proportional to the } \\
\text { accelerator) }\end{array}$ \\
\hline X-ray & Comparable penetration to gamma rays ${ }^{3}$ & $\begin{array}{l}\text { Limited use, uncertain cost estimates } \\
\text { (based on } 2008 \text { IAEA review) }^{3}\end{array}$ \\
\hline
\end{tabular}


was involved, taking over a year to conduct three main phases: 1) preparation of the facility; 2) packaging and shipment of irradiation sources for disposal; 3) disposal/discharge of pool water (used for cooling) and dismantling. Ultimately, all 24,000 curies of cobalt-60 were removed.

Building replacement facilities is also resource-intensive, with food irradiation facilities estimated to cost between \$3-5 million, (https://uw-food-irradiation.engr.wisc.edu/Process.html) and the equipment alone required for an electron accelerator for medical device sterilization estimated to cost between $\$ 1$ and $\$ 2$ million $^{37}$. There is little publicly available information on the full spectrum of cost for Co-60 facilities, including facilities large enough for medical sterilization, but conservatively, they likely cost several million dollars. Consumer products, medical products, and food products that involve Co-60 for sterilization would all be affected by the cost of decommissioning and construction of new facilities for replacement sterilization.

\section{Worldwide impacts}

Restrictions on Co-60 in the US may shift its use to other countries where weaker regulations may have additional economic and security consequences ${ }^{38}$. At a recent IAEA conference on Safety of Radiation Sources and the Security of Radioactive Materials, held in 2000, countries submitted reports describing their use of radiation ${ }^{38}$. Though the regulatory and enforcement status of these countries has likely improved since 2000, the conference proceedings identified several countries with serious regulatory limitations. Angola had begun to use radiation sources, including $\mathrm{Co}-60$, but lacked appropriate infrastructure to control their sources, relying on technical assistance from IAEA and other Member States. Bangladesh was facing financial and administrative hurdles to train and motivate personnel, and to create necessary infrastructure and facilities to achieve safety standards compatible with IAEA International safety standards. To the extent that a national-security motivated phase-out of Co-60 applications in the US shifts Co-60 use to other countries, such changes could aggravate security risks.

A Co-60 phase-out in the US may also increase the cost (and reduce quality) of medical devices and therapies elsewhere. Fifty-percent of the world's sterile single use medical devices come from the US. (http://documentslide.com/documents/ 1 -a-profile-of-the-radiation-source-sector-committee-on-radiation-source-use.html) Depending on the implementation details of a phase-out and transition, there could be an initial decrease in supply of single-use medical devices from the US, as well as a price increase. This outcome could affect the safety and efficacy of healthcare in other countries, particularly those with more limited resources.

\section{Discussion}

The effectiveness, reliability, and predictability of Co-60 have made it a primary source of gamma irradiation for a wide variety of medical and non-medical applications in the US. Its widespread use, though a strength, has also meant that Co-60 can be found in less secured facilities. This potential security concern has led to calls to phase out Co-60 and other radiation sources.

These concerns should be considered in the context of tradeoffs that Co-60 restrictions in the US would impose. These trade-offs include unintended consequences for both medical care and consumer access to products in the US and worldwide. The use of Co-60 for Gamma Knife surgery, sterilization of tissue allografts, and sterilization of single-use medical devices is highly effective and well-documented. Although there are alternative sterilization technologies, they all have limitations. Similarly, Co-60 is used across a range of food products, helping to maintain the quality and safety of food supplies in the US and abroad. Even if acceptable alternative technologies are identified, identifying those alternatives would take time and necessitate costly and lengthy regulatory review.

Just in the US, a phase-out of Co-60 would impose direct monetary costs, time costs, and limitations to access. However, a US phase-out could also shift gamma irradiation processing offshore, particularly for food processing. The establishment of additional Co-60 facilities in countries that may lack rigorous safety and security regulations on par with the US could exacerbate security concerns.

These consequences are not well understood and merit additional research. First, a systematic risk assessment and a cost-benefit analysis of a Co-60 phase-out should be undertaken. The potential trade-offs described in this paper should be quantified and weighed against risk and potential cost of security failure scenarios. An evaluation of efficacy, implementation timeline, and cost for Co-60 alternatives should be included.

Second, a comprehensive assessment of the risk of all radioactive isotopes should be undertaken, along with an evaluation of additional regulatory steps that could shore up security without a complete ban on use of these radiation sources. US regulations for transport, storage, and security already provide a measure of safety. However, given the recent calls for a complete phase-out, it appears more can be done to further improve security.

Lastly, how a phase-out of Co-60 in the US might influence the shift of Co-60 facilities to locations abroad, and how the spread of Co-60 use might influence the threat posed should be carefully evaluated. A follow-up meeting to the year 2000 Safety of Radiation Sources and the Security of Radioactive Materials conference could help to assess the regulatory progress made in each country.

National security concerns are always important, but they can be difficult to assess, particularly when it comes to preventing an event that has yet to occur. However, it is possible to assess the current use of Co-60 in the US and the impact of a potential phase-out. Given its importance across medical and non-medical fields, restrictions on Co-60 merit careful consideration and evaluation before their adoption. 


\section{Author contributions}

Study concept and design were contributed by Chou and Cohen. Data was collected primarily by Skornicki and Chou, with assistance from Cohen, and interpreted by all authors. The manuscript was drafted by Skornicki and Chou, and revised by all authors.

\section{Competing interests}

Skornicki and Chou are employed by Precision Health Economics. Cohen serves as a consultant to Precision Health Economics. The authors have no competing interests to disclose.
Grant information

Sterigenics provided financial support for this research to Precision Health Economics.

The funders had no role in study design, data collection and analysis, decision to publish, or preparation of the manuscript.

\section{Acknowledgments}

Research assistance and support during manuscript outline preparation were provided by Caroline Huber, Kabirraaj Toor, and Lara Yoon. The authors thank Paul Gray of Nordion Inc. (Retired), Nancy Glick of MSL Group, and Kathy Hoffman of Sterigenics, for their helpful feedback.
1. Singh R, Singh D, Singh A: Radiation sterilization of tissue allografts: A review. World J Radiol. 2016; 8(4): 355-69.

PubMed Abstract | Publisher Full Text | Free Full Text

2. American Association of Tissue Banks: About Us. 2016; [cited 2016 October 28] Reference Source

3. Trends in Radiation Sterilization of Health Care Products. International Atomic Energy Agency. 2008 Reference Source

4. Nuclear Energy Institute: Consumer Products. Reference Source

5. US Food and Drug Administration: Premarket Notification PMA. 2017.

6. Elekta: What is Gama Knife? 2016; [cited 2016 October 27]. Reference Source

7. Morehouse KM, Komolprasert V: Irradiation of Food and Packaging: An Overview. 2004.

Reference Source

8. US Food and Drug Administration: Premarket Notification 510(k). 2017 Reference Source

9. Capala J, Goetsch SJ, Orton CG: Point/Counterpoint. Medical use of all high activity sources should be eliminated for security concerns. Med Phys. 2015; 42(12): 6773-5.

PubMed Abstract | Publisher Full Text | Free Full Text

10. Martinez G, Partlow J: Stolen cobalt-60 found in Mexico; thieves may be doomed. The Washington Post. 2013.

Reference Source

11. Neville S: Asos pulls belts in radioactive scare. In The Guardian. 2013.

12. Silindir M, Ozer Y: Sterilization Methods and the Comparison of E-Beam Sterilization with Gamma Radiation Sterilization. FABAD J Pharm Sci. 2009; 34 43-53.

Reference Source

13. Interagency Working Group on Alternatives to High Activity Radioactive Sources (GARS): Transitioning from high-activity radioactive sources to nonradioisotopic (alternative) technologies. A best practices guide for federal agencies. Washington, D.C, 2016; 20502.

Reference Source

14. DiCaprio E, Phantkankum N, Culbertson D, et al.: Inactivation of human norovirus and Tulane virus in simple media and fresh whole strawberries by ionizing radiation. Int J Food Microbiol. 2016; 232: 43-51. PubMed Abstract | Publisher Full Text

15. World Institute for Nuclear Security: Considerations for the Adoption of Alternative Technologies to Replace Radioactive Sources. 2016. Reference Source

16. Industry Experts: Sterilization Technologies: A Global Market Overview. 2016. Reference Source

17. World Nuclear Association: The Many Uses of Nuclear Technology. 2014; [cited 2016 October 28]

Reference Source

18. Komolprasert V: Packaging for Foods Treated by lonizing Radiation. 2007. Publisher Full Text
19. World Nuclear Association: Radioisotopes in Medicine. 2016 Reference Source

20. Interagency Working Group on Alternatives to High-Activity Radioactive Sources, Subcommittee on Nuclear Defense Research and Development, Committee on Homeland and National Security of the National Science and Technology Council: Transitioning from High-Activity Radioactive Sources to Non-Radioisotopic (Alternative) Technologies: A Best Practices Guide for Federal Agencies. 2016. Reference Source

21. Schmidt T, Grabau D, Grotewohl JH, et al.: Does sterilization with fractionated electron beam irradiation prevent $\mathrm{ACL}$ tendon allograft from tissue damage? Knee Surg Sports Traumatol Arthrosc. 2017; 25(2): 584-594. PubMed Abstract | Publisher Full Text

22. Rutala WA, Weber DJ, Health care Infection Control Practices Advisory Committee (HICPAC): Guideline for Disinfection and Sterilization in Healthcare Facilities. Centers for Disease Control and Prevention. 2008. Reference Source

23. Gamma Industry Processing Alliance (GIPA): A Comparison of Gamma, E-beam, $X$-ray and Ethylene Oxide Technologies for the Sterilization of Medical Devices and Other Products. 2017

Reference Source

24. World Overview, Surgical Procedures (000s), in Pharmaceutical Fact Book 2012.

25. Shekelle PG, Wachter RM, Pronovost PJ, et al.: Making health care safer II: an updated critical analysis of the evidence for patient safety practices. Evid Rep Technol Assess (Full Rep). Rockville MD. 2013; (211): 1-945. PubMed Abstract | Free Full Text

26. US Food and Drug Administration: Guidance for Industry: Changes to an Approved NDA or ANDA. US Department of Health and Human Services: Washington, DC. 2004 Reference Source

27. Fölsch C, Kellotat A, Rickert M, et al: Effect of thermodisinfection on mechanic parameters of cancellous bone. Cell Tissue Bank. 2016; 17(3): 427-37. PubMed Abstract | Publisher Full Text

28. Singh $R$, Singh $D$ : Sterilization of bone allografts by microwave and gamma radiation. Int J Radiat Biol. 2012; 88(9): 661-666. PubMed Abstract | Publisher Full Text

29. Kubicek GJ, Turtz A, Xue J, et al:: Stereotactic Radiosurgery for Poor Performance Status Patients. Int J Radiat Oncol Biol Phys. 2016; 95(3): 956-959. PubMed Abstract | Publisher Full Text

30. Watanabe Y, Lee R, Dusenbery KE, et al.: Cumulative Dose to Brain After Multisession Gamma Knife Stereotactic Radiosurgery for Treatment of Multiple Metastatic Tumors. Int J Radiat Oncol Biol Phys. 2016; 96(2): E83. Publisher Full Text

31. Phan J, Yang JN, Ghia AJ, et al:: Dosimetric Comparison of Gamma Knife Extend to Linear Accelerator Base Volumetric Modulated Arc Therapy Plans for Fractionated Stereotactic Radiosurgery. Int J Radiat Oncol Biol Phys. 2015; 93(3): E615-E616. Publisher Full Text

32. Lee WY, Cho DY, Lee HC, et al.: Outcomes and cost-effectiveness of gamma knife radiosurgery and whole brain radiotherapy for multiple metastatic brain 
tumors. J Clin Neurosci. 2009; 16(5): 630-4.

PubMed Abstract | Publisher Full Text

33. Silverman E: FDA still struggling with backlog of generic drug applications March 2, 2016, Dec 2, 2016.

Reference Source

34. Massdevice: Medical device makers spend millions to meet FDA rules, study finds. Medcitizens. 2010.

Reference Source

35. International Atomic Energy Agency: Directory of Gamma Processing Facilities in Member States. Vienna, Austria, 2004.

Reference Source
36.

Bowerman BS, Sullivan PT: Decommissioning the Brookhaven Nationa Laboratory Building 830 Gamma Irradiation Facility. 2001. Publisher Full Text

37. Pharmaceutical \& Medical Packaging News: When in-house sterilization makes sense. 1999.

Reference Source

38. International Atomic Energy Agency: National Regulatory Authorities with

Competence in the Safety of Radiation Sources and the Security of

Radioactive Materials. International Conference of National Regulatory Authorities with Competence in the Safety of Radiation Sources and the Security of Radioactive with Competence in the Safety of Radiation

Reference Source 


\section{Open Peer Review}

\section{Current Peer Review Status:}

\section{Version 1}

Reviewer Report 24 July 2018

https://doi.org/10.5256/f1000research.15326.r34941

(C) 2018 Schreiner L. This is an open access peer review report distributed under the terms of the Creative Commons Attribution License, which permits unrestricted use, distribution, and reproduction in any medium, provided the original work is properly cited.

\section{John Schreiner \\ 1 Departments of Oncology and Physics, Queen's University, Kingston, ON, Canada \\ ${ }^{2}$ Cancer Centre of Southeastern Ontario at the Kingston Health Sciences Centre, Kingston, Ontario, Canada}

The authors have presented quite a complete and compelling analysis of some unintentional and, perhaps, overlooked consequences for the USA and the world if use of the radioisotope cobalt- 60 (Co-60) is severely limited because of security motivated restrictions. They provide the motivation for controlling access to Co-60 sources in their review and analysis. And they lay out some consequences and risks through a good survey of the value of Co-60 in commerce, medicine and agriculture and the potential impact of restrictions. They reason that the restriction of Co- 60 needs to be more carefully analysed, particularly in sterilization and medical applications, since other irradiation technologies and approaches are not yet fully developed for all these applications. They note that the ability to configure the radioactive Co-60 sources in purpose-built devices has provided robust solutions which may not be as easily, or economically, achieved with more technologically complex x-ray or electron irradiators. And associated difficulties of increased complexity and decreased reliability may delay the transition to alternate approaches not yet in place. These are important points that have not been analysed broadly in the literature previously, and to bring them forward here presents a timely and important addition to the literature.

Much of their discussion is limited to select applications in which Co-60 based irradiators have had a lead role in the United States and high income countries (HICs). And the analysis of these applications is quite good but there are two points I would suggest the authors consider in future work regarding the impact of the elimination of Co-60 treatment units in radiation therapy.

1) While the description in the paper on the implications of Gamma-knife restriction does give some context to the importance of Co-60 based brain cancer treatment, it has missed recent technological and clinical developments. The ability to treat small lesions and targets with high energy external beam radiation treatment (EBRT) has been extended to $x$-ray linear accelerator based units; this includes specialised devices and techniques such as small field robotic x-ray units (the CyberKnife, Accuray, Sunnyvale, CA) and advanced EBRT units with volumetric modulated arc 
radiotherapy (VMAT) capabilities that are now available in cancer clinics. That is not to say that the Gamma-knife inventory currently deployed is not a critical resource. It is just to note that alternative devices are already available for this clinical application, although a transition to these devices would have considerable challenges in funding and clinical implementation.

2) A further aspect of radioisotope restriction that could benefit from additional analysis is the impact of the removal of the Co-60 treatment units in low and middle income countries (LMICs) throughout the world. One can argue that the development of high photon energy Co-60 based devices (with effectively $1.25 \mathrm{MeV}$ mono-energetic beams) in the 1950s inaugurated high energy EBRT. As noted by the authors, Co-60 radiation therapy devices have been essentially replaced in much of HICs (aside from select devices such as the Gamma-Knife, the recent ViewRay MRIdian Co-60 Co-60/MRI unit, and some other specialised units). But over 2000 conventional Co-60 EBRT units are still in use in LMICs throughout the world, in large part because of the simple and robust design of these units and the low power and water supply infrastructure requirements for the devices (which often limit the feasibility of linear accelerator based $x$-ray EBRT units in certain locales). This is an important inventory already in place for cancer treatment, particularly in LMICs; the removal of these devices because of Co- 60 security concerns may have critical negative effects.

The World Health Organization has reported that LMICs annually account for over $60 \%$ of the world's new cancer case, yet despite being home to $85 \%$ of the world's population, they have less than $35 \%$ of the world's radiotherapy facilities. The increased burden of cancer and the associated requirement for an increased distribution of EBRT radiation units in LMIC'S has also been highlighted by the International Atomic Energy Agency and the Global Task Force on Radiotherapy for Cancer Control. The restricted availability of Co-60 devices potentially introduces a critical impediment to the important increased deployment of EBRT units as governments and international health agencies work to deal with this deficit. While research groups and radiotherapy vendors are working on developing simpler $x$-ray units for locales with limited infrastructure, it seems there will be a period over which we will rely on the simple Co-60 devices already deployed as well as additional installations (perhaps with new devices specially designed for improved performance and enhanced security of sources) to meet the cancer burden. And, as the authors discuss, the very countries requiring Co-60 radiotherapy deployment may be the same countries where Co-60 security is a challenge. Innovative solutions to ensure availability of needed Co-60 units with effective security control requires attention and the authors may be well set to undertake the analysis and discussion informing such solutions

I have also added some suggested references that discuss some points on Co-60 EBRT in LMICs.

\section{References}

1. Van Schelt J, Smith DL, Fong N, Toomeh D, et al.: A ring-based compensator IMRT system optimized for low- and middle-income countries: Design and treatment planning study.Med Phys. 2018; 45 (7): 3275-3286 PubMed Abstract | Publisher Full Text

2. Dhanesar S, Darko J, Joshi CP, Kerr A, et al.: Cobalt-60 tomotherapy: clinical treatment planning and phantom dose delivery studies.Med Phys. 2013; 40 (8): 081710 PubMed Abstract | Publisher Full Text

3. Schreiner LJ, Joshi CP, Darko J, Kerr A, et al.: The role of Cobalt-60 in modern radiation therapy: Dose delivery and image guidance.J Med Phys. 2009; 34 (3): 133-6 PubMed Abstract | Publisher Full Text 
Is the topic of the opinion article discussed accurately in the context of the current literature?

Yes

Are all factual statements correct and adequately supported by citations? Partly

Are arguments sufficiently supported by evidence from the published literature? Yes

Are the conclusions drawn balanced and justified on the basis of the presented arguments? Yes

Competing Interests: I have had two provincial - industry matched funding for Co-60 research (advancing $x$-ray based radiation therapy techniques from $x$-ray units to Co-60 units) with BEST Theratronics (a Co-60 unit manufacturer in Kanata Canada) as the industrial partner. No personal gain but funded research and graduate students.

Reviewer Expertise: Medical physics and radiation therapy.

I confirm that I have read this submission and believe that I have an appropriate level of expertise to confirm that it is of an acceptable scientific standard.

Reviewer Report 17 April 2018

https://doi.org/10.5256/f1000research.15326.r32270

(C) 2018 Goetsch S. This is an open access peer review report distributed under the terms of the Creative Commons Attribution License, which permits unrestricted use, distribution, and reproduction in any medium, provided the original work is properly cited.

\section{Steven J. Goetsch}

1 San Diego Gamma Knife Center, San Diego, CA, USA

2 Radiological Technologies University VT, South Bend, IN, USA

Jacqueline Chou and others have done an excellent job of evaluating the consequences to the United States from a ban of Co-60 gamma emitting radioisotopes in medicine and industry. The problem is actually far larger than that. Several more gamma emitting isotopes are also in widespread use. Gamma radiation from Co-60 is highly penetrating which makes it ideal for some applications and unsuitable for others. It is comparable in energy to a $4 \mathrm{MV}$ linear accelerator.

Many medical devices contain Cesium-137. This isotope has a much longer half-life than Co-60 (30 years vs. 5.26 years) and emits gamma radiation with much lower energy, making it easier to shield. It is the isotope of choice for blood irradiators. Much of the US blood supply is irradiated before infusing into human patients, particularly those who are immune-compromised. 
Another extremely prevalent isotope is Ir-192.This isotope of iridium emits a multiplicity of gamma rays with about half the average energy of Cs-137 and one fourth the mean energy of Co-60 gamma radiation. Ir-192 is most commonly used in industrial radiography. There are literally thousands of such devices used in almost every major construction site in the country involving the use of structural steel. There is no other practical way to verify the competence of welding at a construction site which is vital to the safety of the bridges and buildings under construction.

Another important field which makes extensive use of radioisotope sources is the oil and gas drilling industry. Well logging sources (primarily Cs-137 and Americium-241 mixed with beryllium) are inserted into a well and reflected radiation is analyzed to determine the geologic structure of the layer being penetrated.

Each of these applications is important and very difficult to replace with radiation producing electronic devices.

Is the topic of the opinion article discussed accurately in the context of the current literature?

Yes

Are all factual statements correct and adequately supported by citations? Yes

Are arguments sufficiently supported by evidence from the published literature? Yes

Are the conclusions drawn balanced and justified on the basis of the presented arguments? Yes

Competing Interests: No competing interests were disclosed.

Reviewer Expertise: I have performed Gamma Knife radiosurgery for the last 23 years.

I confirm that I have read this submission and believe that I have an appropriate level of expertise to confirm that it is of an acceptable scientific standard. 
The benefits of publishing with F1000Research:

- Your article is published within days, with no editorial bias

- You can publish traditional articles, null/negative results, case reports, data notes and more

- The peer review process is transparent and collaborative

- Your article is indexed in PubMed after passing peer review

- Dedicated customer support at every stage

For pre-submission enquiries, contact research@f1000.com 